\section{塵 脑・粉 塵}

\section{Byssinosis (綿肺症)に関する労衝衛生学的研究 製綿工場従業員の実態と Byssinosis 症例の検討——}

奥谷博俊, 島 正吾, 原田 昭, 近藤正人 松浦洋治, 奥山 静 (名市大医公衛)

綿じん，原綿夾雑物の吸入によって発症するByssinosis（綿肺症）は，当該職場に多発し，とき重篤な 心肺系障害を招来する瞕業性呼吸器疾品としてしられ る。私どもは過去数年来，各種原綿取扱い作業における 本症浸滛の実態を調查してきたが，今回，愛知県下製綿 工場の混打綿粗紡工に本症第一例を発見し，末た併せ て，本邦では報告をみない本工程就業初期にみる特異な 症候群（仮称 cotton fever）の多発を経験し, 動物実験

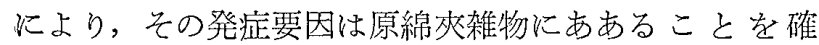
認，さらに Byssinosis との関連についても検傠を行な っている。

対象工場の気中粉じん量は, 混打綿 $4.0 \sim 7.7 \mathrm{mg} / \mathrm{m}^{3}$, 梳綿・粗紡 $3.2 \sim 7.0 \mathrm{mg} / \mathrm{m}^{3}$ で，有機粉じんが大半をし め，その他現場には環境衛生学的配虑はほと九ぞなされ ていない, 私どものいら cotten fever そは, 同工程従 事者の $60 \%$ に, 初就業 1 7 日以内, ときに休日あけ 飞, 中等熱, 熱感, 頭痛, 悪感, 酔感, 全身俈怠感等多 彩な症候を認め, いずれも7日以内軽快している。就 業時年令, 既往歴, 泪煙歴とは相関はない。胸部レ線上 軽〜中等度異常線状影を過半数隹認め, 現症として慢性 気管支炎 6 名, さらに全員の経時的肺换気機能の推移よ り，混打綿・粗紡工の作業な機能低下をみた。

本工程で発見した Bysinosis 第1例とは，42才，男 子, 生来健康, 21 才て混打綿工として就業, 入社 2 日後 息切れ，悪感，中等熱，頭痛等により休業，その後短期 間に同症状を反復し，前後 3 回にわたり，入・退社をく り返したがなな秥混打綿工として現在にいたる。35才 (大社後 14 年), 作業後突然強度の胸部絞拒感, 息切れに より, 半ば失心状態となり受診, 最近までに作業後, 休 日あけに $3 \sim 4$ 回, 同椂発作をみた。原綿夾雑物抽出蛋 白による皮内反応陽性, $(25 \times 25 \mathrm{~mm})$, 胸部レ線所見 は軽度肺絞理增強, 肺換気機能, 肺拡散機能に軽度障害 あり。その他脳波，心電図をらさ各種理学的所見には 特記すべきものはない。な扡化本症軽症例 3 名あり。 連続16日間汸たる作業前後の肺換気機能の推移をみ,
日間変動，週間変動，学働時間等との関連に叔いて與味 ある知見を觉た。

\section{4．亜鉛金属鉱山のじん肺，じん肺結核の管理}

乗松克政（九大医胸研）

昭和 30 年以来13年間，九州の某亜鉛鈆山従事者約 800 名（粉じん職歷者約450名）のじん肺，じん肺結核の健 康管理を行なってきており，10年間の成績は第39回総会 で報告したが，さらにその後の経過について整理総括 し， レ線所見の経年的変化，肺機能検查成績，じん肺結 核切除 9 例の遠隔成績执よび INH 飞よる結核の発病防 止対策沉つき報告する。

1）現在じん肺結核 $\mathbb{N}$ 症度で入院中のもの 3 名で，じ 几肺有所見者は $\mathrm{PR}_{4} 1$ 名, $\mathrm{PR}_{3} 3$ 名, $\mathrm{PR}_{2} 10$ 名, $\mathrm{PR}_{1}$ 82名, PRx 116名である。職歴年数とレ線の変化は一般 に年数の長い程炎の变化は多いが，必ずしも平行しない ものがある。

2）肺機能検查成績は入院中の 2 名が $F_{3} て ゙ ， F_{2} 1$ 名, $F_{1} 5$ 名その他は $\mathrm{F}_{0}$ であった。

3）じん肺結核切除 9 例の中 10 年以上の遠隔成績は, 術後非粉じん職場への配置転換を行なってはいるが， 7 例すべてじん肺の進展がみられかっその中 3 例は高度に 進展している。

4） レ線上 PRx 以上の約 100 例伦 $2 \sim 4$ 年間, INH を投与してきたが，その中から結核の発生は 1 例及られ ている。

な特鉱山は九州の舒島にあり，紛じん作業者の移動が 少なく，長期水たって経過観察し得る利点から管理成 績をまとめ健管の方策に資した。

\section{5. 各種じん肺組織にむける粉じん量と組織反応量に ついて（第 2 報）}

\section{阿部 彰（東京労災病院内科）} 中島彬恭（労研病理）

じん肺に怙ける粉じん紧中の粉じんの定性, 定量分析 を行ない，同一粉じん量により形成される粉じん巣の程 度を, 各種じん肺について比较し,その結果は 40 年度本学 会総会に報告した。今回は爾後に検索した症例を加兄， 粉じん相互間の粉じん栄形成の強弱を，珪肺を指標とし て求めた。またさらに肺の一部の粉じんを分析し積分法 を使用して，肺全体の粉じん総量を測定しえたので報告 する。 